\title{
PENGARUH KEPUASAN KARYAWAN TERHADAP KINERJA KARYAWAN DENGAN KOMITMEN ORGANISASI SEBAGAI VARIABEL INTERVENING (SURVAI PADA PERGURUAN TINGGI SWASTA DI WILAYAH JAKARTA BARAT)
}

\author{
Budi Hartono Kusuma \\ Lina \\ Universitas Pelita Harapan \\ Email: budi.kusuma@uph.edu; lina.fe@uph.edu
}

Submitted: Sep 11, 2017; Reviewed: Sep 13, 2017; Accepted: Jan 30, 2018

\begin{abstract}
The aim of this study is to provide empirical evidence of the positive influence of employee satisfaction on employee performance. Employee commitment as intervening variable also wants to be proven through this research. The data used is primary data. Data were obtained through questionnaires distributed to respondents. The respondents were chosen by using purposive sampling method based on certain criteria. The criteria set are as follows: full-time lecturer or homebase lecturer at private universities in West Jakarta area. Hypothesis test uses regression analysis and path analysis. The results showed that employee satisfaction has a positive influence on employee performance. Employee commitment as intervening variable can not be proven through this research.
\end{abstract}

Keywords: Employee Commitment; Employee Performance; Employee Satisfaction.

\section{PENDAHULUAN}

Menurut Horngren et al (2015), sistem pengendalian manajemen adalah sarana untuk mengumpulkan dan menggunakan informasi untuk membantu dan mengkoordinasikan keputusan perencanaan dan pengendalian di seluruh organisasi. Sistem pengendalian manajemen juga bermanfaat untuk memandu perilaku para manajer dan karyawan lainnya. Horngren et al (2015) menguraikan bahwa sistem pengendalian manajemen terdiri dari 2 faktor, yaitu faktor formal dan faktor informal. Faktor formal mencakup aturan, prosedur, ukuran kinerja, dan rencana insentif yang jelas yang memandu perilaku manajer dan karyawan lainnya. Faktor informal mencakup nilai bersama, loyalitas, dan komitmen bersama di antara anggota organisasi, budaya perusahaan, dan norma tidak tertulis tentang perilaku yang dapat diterima bagi manajer dan karyawan lainnya. Sistem pengendalian manajemen yang didesain dengan baik menggunakan informasi yang berasal dari dalam dan dari luar organisasi. Salah satu informasi dari dalam yang digunakan adalah tingkat kepuasan karyawan. Sistem pengendalian manajemen yang efektif dijalankan seharusnya dapat memotivasi seluruh anggota organisasi untuk melakukan upaya terbaik dalam bentuk kinerja maksimal guna mencapai goal congruence.

Sejumlah penelitian terdahulu membuktikan bahwa kepuasan yang dicapai oleh seorang karyawan memiliki pengaruh positif secara langsung terhadap kinerja yang dicapai oleh karyawan yang bersangkutan. Brahmasari dan Suprayetno (2008) menyimpulkan secara umum bahwa kepuasan kerja karyawan yang tinggi akan mampu meningkatkan kinerja perusahaan. Hasil penelitian Nur (2013) menunjukkan bahwa semakin tinggi tingkat kepuasan kerja akan memberikan dampak positif dalam meningkatkan kinerja pegawai. Penelitian Putri dan Latrini (2013) juga menunjukkan hasil yang sama yaitu kepuasan karyawan 
berpengaruh terhadap kinerja karyawan. Devi (2009) berhasil membuktikan bahwa variabel kepuasan kerja dan motivasi menunjukkan pengaruh yang signifikan positif terhadap kinerja karyawan. Salah satu hasil dari penelitian Taurisa dan Ratnawati (2012) membuktikan bahwa kepuasan kerja berpengaruh positif dan signifikan terhadap kinerja karyawan. Hasil ini konsisten dengan penelitian yang dilakukan oleh Rosita dan Yuniati (2016) serta Fauzi et al (2016). Penelitian Rosita dan Yuniati (2016) bertujuan untuk menguji pengaruh kepuasan kerja terhadap kinerja karyawan dengan komitmen organisasi sebagai variabel intervening. Penelitian ini mencoba untuk menggali keberadaan variabel mediasi pada pengaruh kepuasan kerja terhadap kinerja karyawan. Hasil dari penelitian dapat membuktikan komitmen organisasional merupakan variabel intervening yang signifikan pada pengaruh kepuasan kerja terhadap kinerja karyawan.

Penelitian ini menggunakan dosen sebagai responden. Kriteria yang ditetapkan adalah dosen penuh waktu atau dosen homebase di perguruan tinggi swasta yang berlokasi di Jakarta Barat. Dosen adalah profesi yang unik. Sebagai dosen di Indonesia, pemerintah menuntut terpenuhinya unsur Tri Dharma Perguruan Tinggi yaitu melakukan pengajaran, penelitian, dan pengabdian kepada masyarakat. Selain itu, dosen juga memiliki tanggung jawab lain seperti menjadi penasehat akademik, pembimbing tugas akhir, pendamping berbagai kegiatan mahasiswa, pengawas ujian, dan pelaksana tugas-tugas administratif lainnya. Dosen juga harus dapat menyesuaikan diri dengan para kolega, mahasiswa bahkan orang tua murid. Menguji secara empiris pengaruh kepuasan dosen terhadap kinerja dosen yang bersangkutan merupakan hal yang menarik. Komitmen dosen sebagai variabel intervening juga menjadi hal yang juga menarik untuk dibuktikan secara empiris.

Generasi Penelitian ini diharapkan dapat memberikan kontribusi bagi pengembangan literatur khususnya dalam bidang sistem pengendalian manajemen terkait pengukuran kinerja serta dalam bidang penelitian perilaku. Penelitian ini juga diharapkan dapat memberikan manfaat bagi manajemen perguruan tinggi swasta dalam mengelola sumber daya khususnya dosen. Pengelolaan dosen secara optimal pada akhirnya dapat meningkatkan kualitas pendidikan di Indonesia.

\section{Rumusan Masalah:}

Berdasarkan uraian yang ada, maka rumusan masalah dalam penelitian ini adalah: 1). Apakah kepuasan karyawan berpengaruh positif terhadap kinerja karyawan? 2). Apakah kepuasan karyawan berpengaruh positif terhadap kinerja karyawan dengan komitmen karyawan sebagai variabel intervening?

\section{Tujuan Penelitian:}

Mengacu pada rumusan masalah di atas, maka penelitian ini bertujuan untuk memberikan bukti empiris mengenai: 1). Pengaruh positif kepuasan karyawan terhadap kinerja karyawan. 2). Pengaruh positif kepuasan karyawan terhadap kinerja karyawan dengan komitmen karyawan sebagai variabel intervening.

\section{TINJAUAN PUSTAKA \\ Kepuasan Karyawan}

Al Afghoni dan Wahyudi (2011) mendefinisikan kepuasan karyawan terhadap pekerjaannya sebagai suatu keadaan emosional yang menyenangkan atau tidak menyenangkan bagi seseorang terhadap pekerjaan yang ditekuninya. Koesmono (2005) mengemukakan bahwa kepuasan kerja merupakan penilaian, perasaan, atau sikap seseorang atau karyawan terhadap pekerjaannya dan terhadap sejumlah faktor lainnya seperti lingkungan kerja, jenis pekerjaan, kompensasi, hubungan antar teman kerja, hubungan sosial di tempat kerja dan sebagainya. Pada akhirnya dapat dikatakan bahwa kepuasan kerja adalah dapat dipenuhinya beberapa keinginan dan kebutuhan melalui kegiatan kerja atau bekerja. Nur (2013) mengungkapkan bahwa kepuasan kerja seseorang tergantung pada selisih antara harapan, kebutuhan, atau nilai dengan apa yang menurut pandangan atau persepsinya yang telah dicapai melalui pekerjaannya. Jadi, seseorang akan merasakan puas jika tidak ada perbedaan antara apa yang diinginkan dengan apa yang sesungguhnya terjadi, sebaliknya, apabila terdapat perbedaan antara apa yang diinginkan dengan kenyataan, maka seseorang akan merasakan tidakpuas. Dapat disimpulkan bahwa yang dimaksud dengan kepuasan kerja adalah kumpulan perasaan dan kepercayaan yang dimiliki oleh seorang karyawan, baik yang menyenangkan (emosi positif) dan tidak menyenangkan (emosi negatif) tentang pekerjaannya. 


\section{Komitmen Karyawan}

Komitmen karyawan didefinisikan sebagai suatu keadaan dimana seseorang karyawan memihak organisasi tertentu serta tujuan-tujuan dan keinginannya untuk mempertahankan keanggotaan dalam organisasi tersebut. Komitmen organisasional yang tinggi berarti memihak organisasi yang merekrut individu tersebut. (Robbins, 2008). Komitmen organisasi cenderung didefinisikan sebagai suatu perpaduan antara sikap dan perilaku. Komitmen organisasional menyangkut tiga sikap yaitu, rasa mengidentifikasi dengan tujuan organisasi, rasa keterlibatan dengan tugas organisasi, dan rasa kesetiaan kepada organisasi (Trisnaningsih 2011). Al Afghoni dan Wahyudi (2011) mengungkapkan komitmen organisasi merupakan tingkat sampai sejauh mana seorang karyawan memihak pada suatu organisasi tertentu dan tujuan-tujuan yang ada, serta berniat untuk mempertahankan keanggotaannya dalam organisasi itu.

\section{Kinerja Karyawan}

Dessler (2009) mengungkapkan bahwa kinerja (prestasi kerja) karyawan adalah prestasi aktual karyawan dibandingkan dengan prestasi yang diharapkan dari karyawan. Prestasi kerja yang diharapkan adalah prestasi standar yang disusun sebagai acuan sehingga dapat melihat kinerja karyawan sesuai dengan posisinya dibandingkan dengan standar yang dibuat. Selain itu dapat juga dilihat kinerja dari karyawan tersebut dibandingkan dengan karyawan lainnya. Brahmasari dan Suprayetno (2008) menyatakan bahwa setiap manusia mempunyai potensi untuk bertindak dalam berbagai bentuk aktivitas. Kemampuan bertindak itu dapat diperoleh manusia baik secara alami (ada sejak lahir) atau dipelajari. Walaupun manusia mempunyai potensi untuk berperilaku tertentu tetapi perilaku itu hanya diaktualisasikan pada saat-saat tertentu saja. Potensi untuk berperilaku tertentu itu disebut ability (kemampuan), sedangkan ekspresi dari potensi ini dikenal sebagai performance (kinerja). Mangkunegara (2010) mendefiniskan kinerja karyawan (prestasi kerja) sebagai hasil kerja secara kualitas dan kuantitas yang dicapai oleh seorang karyawan dalam melaksanakan tugasnya sesuai dengan tanggung jawab yang diberikan kepadanya. Menurut Nur (2013), kinerja (performance) pada umumnya diartikan sebagai kinerja, hasil kerja, atau prestasi kerja. Kinerja memiliki makna yang cukup luas, bukan hanya menyatakan sebagai hasil kerja, tetapi juga bagaiaman proses kerja berlangsung. Kinerja adalah tentang melakukan pekerjaan dan hasil yang dicapai dari pekerjaan tersebut. Mengelola kinerja sebaiknya dilakukan secara kolaboratif dan kooperatif antara pegawai dan pemimpin organisasi, serta melalui pemahaman dan penjelasan kinerja dalam suatu kerangka kerja atas tujuan-tujuan terencana, standar, dan kompetensi yang disetujui bersama. Kinerja karyawan diukur berdasarkan standar atau kriteria yang telah ditetapkan oleh perusahaan. Perusahaan perlu melihat kinerja sumber daya manusia sebagai isu strategis dan juga sebagai alat untuk membantu mencapai keunggulan kompetitif (Djastuti, 2010).

\section{Kepuasan Karyawan dan Kinerja Karyawan} Brahmasari dan Suprayetno (2008) melakukan penelitian dengan menggunakan populasi seluruh karyawan PT Pei Hai International Wiratama Indonesia di Surabaya dan Jombang. Hasil penelitian ini membuktikan bahwa kepuasan kerja karyawan berpengaruh positif dan signifikan terhadap kinerja perusahaan, artinya bahwa secara umum kepuasan kerja karyawan yang tinggi akan mampu meningkatkan kinerja perusahaan. Tujuan penelitian Nur (2013) adalah untuk mengetahui pengaruh konflik, stres kerja, dan kepuasan kerja terhadap kinerja Pegawai Universitas Khairun Metode penelitian yang digunakan adalah metode survey pada Pegawai Negeri Sipil Universitas Khairun Ternate. Sampel penelitian adalah 105 Pegawai Negeri Sipil. Teknik yang digunakan untuk menguji hipotesis adalah analisis Jalur Hasil penelitian membutikan bahwa kepuasan kerja berpengaruh positif terhadap kinerja pegawai artinya semakin tinggi tingkat kepuasan kerja akan memberikan dampak positif dalam meningkatkan kinerja pegawai. Tujuan penelitian Putri dan Latrini (2013) adalah untuk mengetahui pengaruh kepuasan kerja terhadap kinerja organisasi sektor publik dengan in-role performance dan innovative performance sebagai variabel mediasi. Penelitian ini dilakukan di PDAM Kabupaten Badung, Tabanan dan Kota Denpasar. Metode pengambilan sampel menggunakan metode purposive sampling dengan mengambil sebanyak 200 responden dari populasi karyawan sebanyak 902 orang. Hasil penelitian menunjukkan bahwa semua variabel berpengaruh positif terhadap kinerja karyawan. Penelitian Devi (2009) bertujuan untuk menganalisis kinerja karyawan outsourcing PT Semeru Karya Buana Semarang. Penelitian ini menggunakan 
variabel kepuasan kerja dan motivasi untuk menganalisis pengaruh kinerja karyawan outsourcing tersebut. Hasil penelitian menunjukkan bahwa variabel kepuasan kerja dan motivasi menunjukkan pengaruh yang signifikan positif terhadap kinerja karyawan. Tujuan dari penelitian Taurisa dan Ratnawati (2012) adalah untuk menganalisis pengaruh budaya organisasi, kepuasan kerja, dan komitmen organisasional terhadap kinerja karyawan. Adapun objek penelitian yang dipilih dalam studi ini adalah PT Sido Muncul Kaligawe Semarang. Data dikumpulkan melalui metode kuesioner yang diisi secara mandiri terhadap 127 responden dengan menggunakan metode sensus. Salah satu hasil dari penelitian ini membuktikan bahwa kepuasan kerja berpengaruh positif dan signifikan terhadap kinerja karyawan. Hasil ini konsisten dengan penelitian yang dilakukan oleh Rosita dan Yuniati (2016). Melalui penelitiannya, Fauzi et al (2016) menyimpulkan bahwa ada pengaruh positif yang signifikan antara kepuasan kerja terhadap kinerja karyawan. Hal ini mengindikasikan bahwa kepuasan kerja merupakan faktor yang mempengaruhi kinerja karyawan. Jika kepuasan kerja tinggi maka juga dapat meningkatkan kinerja karyawan. Penelitian Al Afghoni dan Wahyudi (2011) menunjukkan hasil yang berbeda yaitu kepuasan kerja tidak memiliki pengaruh terhadap kinerja.

Kepuasan Karyawan, Komitmen Karyawan, dan Kinerja Karyawan

Penelitian Rosita dan Yuniati (2016) bertujuan untuk menguji pengaruh kepuasan kerja terhadap kinerja karyawan dengan komitmen organisasi sebagai variabel intervening. Populasi dalam penelitian ini adalah seluruh karyawan pada PT Pharos Indonesia Surabaya, pada bagian gudang, IT, quality control, accounting, marketing dan kepala bagian operasional. Sampel dalam penelitian berjumlah 125 responden, dipilih dengan menggunakan teknik simple random sampling. Hasil dari penelitian dapat membuktikan komitmen organisasional merupakan variabel intervening yang signifikan dalam hubungan antara kepuasan kerja dan kinerja karyawan. Al Afghoni dan Wahyudi (2011) melakukan penelitian mengenai pengaruh kompensasi dan kepuasan kerja terhadap kinerja guru dengan komitmen organisasi sebagai variabel intervening. Penelitian ini dilakukan terhadap para guru di SD Kampus Kuripan Kecamatan Purwodadi Kabupaten Grobogan. Hasil penelitian menunjukkan bahwa komitmen 130 organisasi tidak mampu memediasi pengaruh kompensasi dan kepuasan kerja terhadap kinerja guru.

\section{HIPOTESIS PENELITIAN}

$\mathrm{H}_{1}$ Kepuasan karyawan berpengaruh positif terhadap kinerja karyawan.

$\mathrm{H}_{2}$ Kepuasan karyawan berpengaruh positif terhadap kinerja karyawan dengan komitmen karyawan sebagai variabel intervening.

\section{MODEL PENELITIAN}

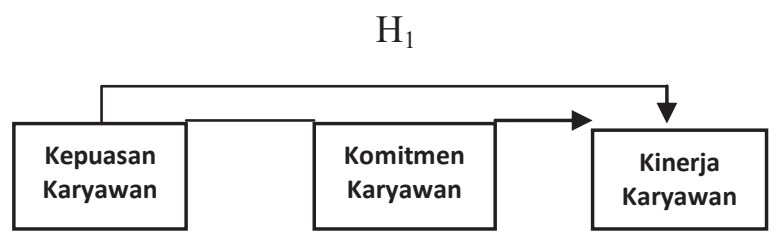

Gambar 1. Model Penelitian

\section{POPULASI}

Populasi dalam penelitian ini adalah dosen tetap atau dosen homebase pada perguruan tinggi swasta di wilayah Jakarta Barat. Sampel dipilih menggunakan metode purposive sampling dengan menggunakan kriteria yaitu dosen tetap atau dosen homebase pada Fakultas Ekonomi perguruan tinggi swasta di wilayah Grogol, Jakarta Barat. Karakteristik respoonden berdasarkan umur, jenis kelamin, tingkat pendidikan, program studi, dan status dosen dapat dilihat pada tabel di bawah ini.

Tabel 1. Demografik Responden

\begin{tabular}{lr}
\hline \multicolumn{1}{c}{ Demografik } & \multicolumn{1}{c}{ Nilai } \\
\hline Jumlah responden & 91 \\
UMUR & \\
Rata-rata & 39,51 \\
Interval & $22-69$ \\
Standar Deviasi & 11,07 \\
\hline JENIS KELAMIN & \\
Pria & $38(41,76 \%)$ \\
Wanita & $53(58,24 \%)$ \\
\hline TINGKAT PENDIDIKAN & \\
S1 & $3(3,29 \%)$ \\
S2 & $76(83,52 \%)$ \\
S3 & $12(13,19 \%)$ \\
\hline PROGRAM STUDI & \\
Manajemen & $29(31,87 \%)$ \\
Akuntansi & $62(68,13 \%)$ \\
\hline STATUS & \\
Dosen Tetap & $79(86,81 \%)$ \\
Dosen Homebase & $12(13,19 \%)$ \\
\hline
\end{tabular}


Data primer digunakan dalam penelitian ini. Data diperoleh melalui penyebaran kuesioner kepada para responden. Berikut ini disajikan ringkasan kuesioner yang diperoleh.

Tabel 2. Ringkasan Kuesioner

\begin{tabular}{lc}
\hline Keterangan & Jumlah \\
\hline Kuesioner yang didistribusikan & 120 \\
\cline { 2 - 2 } Kuesioner yang diterima kembali & 96 \\
Kuesioner yang tidak lengkap diisi & 5 \\
\cline { 2 - 2 } Kuesioner yang digunakan & 91 \\
\hline
\end{tabular}

DEFINISI OPERASIONAL VARIABEL

Kepuasan karyawan adalah variabel independen. Variabel ini diukur dengan 9 pernyataan yang dikembangkan oleh Spector (2001) dan telah dimodifikasi. Semua pernyataan diukur pada skala likert lima point. Variabel dependen adalah kinerja karyawan yang diukur dengan 9 pernyataan. Pernyataan ini dikembangkan oleh Vignaswaran (2005) dan Gallato (2012). Komitmen karyawan merupakan variabel intervening yang diukur dengan 7 pernyataan. Pernyataan ini dikembangkan oleh Allen dan Meyer (1990).

\section{METODE ANALIS DATA \\ Uji Kualitas Data \\ Uji Validitas}

Untuk menentukan kualitas data primer, perlu dilakukan uji validitas terlebih dahulu. Menurut Ghozali (2011), uji validitas adalah uji yang digunakan untuk mengukur sah atau valid tidaknya suatu kuesioner. Suatu kuesioner dikatakan valid jika pertanyaan atau pernyataan pada kuesioner mampu untuk mengungkapkan sesuatu yang akan diukur oleh kuesioner tersebut. Analisis korelasi bivariate dengan melihat pearson coefficients correlation antara masing-masing skor indikator dengan total skor konstruk akan digunakan untuk uji validitas dalam penelitian ini.

\section{Uji Reliabilitas}

Uji kualitas data yang perlu dilakukan berikutnya adalah uji reliabilitas. Ghozali (2011) mengungkapkan bahwa uji reliabilitas adalah pengujian yang dilakukan untuk memastikan bahwa jawaban atau tanggapan responden terhadap pertanyaan atau pernyataan adalah konsisten dari waktu ke waktu. Jika suatu konstruk atau variabel memiliki nilai cronbach alpha $>0.70$ maka dapat dikatakan konstruk atau variabel tersebut adalah reliable (Nunnaly, 1994 dalam Ghozali 2011).

\section{Uji Hipotesis}

\section{Uji Koefisien Korelasi}

Uji koefisien korelasi atau uji $\mathrm{R}$ digunakan untuk menguji hubungan antara variabel independen dengan variabel dependen. Jika nilai $\mathrm{R}$ adalah lebih besar dari 0,5 maka hubungan antara variabel independen dengan variabel dependen adalah kuat (Ghozali, 2011).

\section{Uji Koefisien Determinasi}

Uji koefisien determinasi atau uji $\mathrm{R}^{2}$ digunakan untuk menentukan seberapa besar variasi variabel dependen (Y) dapat dijelaskan oleh variasi variabel independen (X). Menurut Ghozali (2011), nilai koefisien determinasi berkisar antara 0 sampai 1 . Nilai $\mathrm{R}^{2}$ mendekati nol berarti kemampuan variabel independen dalam menjelaskan variasi variabel dependen sangat terbatas. Sebaliknya, jika nilai mendekati 1 berarti variabel independen memberikan hampir semua informasi yang dibutuhkan untuk memprediksi variasi variabel dependen. (Ghozali 2011).

\section{Analisis Jalur}

Untuk menjawab hipotesis pertama yaitu pengaruh penilaian kinerja terhadap kinerja karyawan, penelitian ini menggunakan uji t. Untuk menjawab hipotesis kedua yaitu pembuktian komitmen karyawan sebagai variabel intervening, digunakan analisis jalur. Standardized beta akan digunakan sebagai koefisien jalur.

\section{Hasil dan Pembahasan \\ Uji Kualitas Data \\ Uji Validitas}

Melalui uji pearson correlation akan diperoleh nilai $\mathrm{r}$ hitung. Dengan jumlah responden 91, degree of freedom 90, dan tingkat signifikansi $5 \%$ maka didapat nilai $r$ tabel adalah 0,205 . Nilai $r$ hitung akan dibandingkan dengan nilai $r$ tabel. Jika nilai $r$ hitung lebih besar daripada nilai $r$ tabel maka dikatakan valid. Hasil uji validitas dalam penelitian ini dapat dilihat pada tabel $3-5$ berikut ini. Semua butir pernyataan dapat dikatakan valid. 
Tabel 3. Hasil Uji Validitas - Kepuasan Karyawan

\begin{tabular}{cccc}
\hline Butir Pernyataan $\mathrm{r}$ hitung $\mathrm{r}$ tabel & Keterangan \\
\hline 1 & 0,754 & 0,205 & Valid \\
2 & 0,808 & 0,205 & Valid \\
3 & 0,812 & 0,205 & Valid \\
4 & 0,786 & 0,205 & Valid \\
5 & 0,815 & 0,205 & Valid \\
6 & 0,802 & 0,205 & Valid \\
7 & 0,694 & 0,205 & Valid \\
8 & 0,722 & 0,205 & Valid \\
9 & 0,673 & 0,205 & Valid \\
\hline
\end{tabular}

Sumber: Hasil Pengolahan SPSS

Tabel 4. Hasil Uji Validitas - Komitmen Karyawan

\begin{tabular}{cccc}
\hline Butir Pernyataan $\mathrm{r}$ hitung & $\mathrm{r}$ tabel & Keterangan \\
\hline 1 & 0,757 & 0,205 & Valid \\
2 & 0,701 & 0,205 & Valid \\
3 & 0,701 & 0,205 & Valid \\
4 & 0,829 & 0,205 & Valid \\
5 & 0,771 & 0,205 & Valid \\
6 & 0,658 & 0,205 & Valid \\
7 & 0,752 & 0,205 & Valid \\
\hline
\end{tabular}

Sumber: Hasil Pengolahan SPSS

Tabel 5. Hasil Uji Validitas - Kinerja Karyawan

\begin{tabular}{cccc}
\hline Butir Pernyataan $\mathrm{r}$ hitung $\mathrm{r}$ tabel & Keterangan \\
\hline 1 & 0,683 & 0,205 & Valid \\
2 & 0,703 & 0,205 & Valid \\
3 & 0,624 & 0,205 & Valid \\
4 & 0,617 & 0,205 & Valid \\
5 & 0,657 & 0,205 & Valid \\
6 & 0,554 & 0,205 & Valid \\
7 & 0,678 & 0,205 & Valid \\
8 & 0,729 & 0,205 & Valid \\
9 & 0,714 & 0,205 & Valid \\
\hline
\end{tabular}

Sumber: Hasil Pengolahan SPSS

\section{Uji Reliabilitas}

Pengujian reliabilitas menunjukkan bahwa semua nilai cronbach's alpha di atas 0,70 sehingga dapat dikatakan bahwa tanggapan responden atas butir pernyataan adalah konsisten dari waktu ke waktu.
Tabel 6. Hasil Uji Reliabilitas

\begin{tabular}{lcc}
\hline \multicolumn{1}{c}{ Variabel } & Cronbach's Alpha & Keterangan \\
\hline Kepuasan Karyawan & 0,780 & Reliable \\
Komitmen Karyawan & 0,783 & Reliable \\
Kinerja Karyawan & 0,763 & Reliable \\
\hline
\end{tabular}

Sumber: Hasil Pengolahan SPSS

\section{Uji Hipotesis}

Uji hipotesis pertama menunjukkan hasil berikut ini. Uji koefisien korelasi menunjukkan angka sebesar 0,392. Artinya tidak terdapat hubungan yang kuat antara variabel kepuasan karyawan dengan kinerja karyawan. Nilai koefisien determinasi sebesar 0.154 artinya variasi variabel kinerja karyawan dapat dijelaskan oleh variasi variabel kepuasan kerja sebesar $15,4 \%$. Sisanya dijelaskan oleh variabel lain yang tidak dimasukkan dalam penelitian ini. Hasil uji $\mathrm{t}$ menunjukkan nilai signifikansi sebesar 0,000 dengan nilai koefisien sebesar 0,248. Hipotesis pertama yang menyatakan bahwa kepuasan karyawan memiliki pengaruh positif terhadap kinerja karyawan dapat dibuktikan melalui hasil penelitian ini. Karyawan dalam penelitian ini adalah dosen. Dosen yang merasa puas dengan kebijakan, lingkungan kerja, serta kompensasi yang diberikan oleh perguruan tinggi tempat mereka bekerja pada akhirnya akan memiliki dampak terhadap kinerja dosen yang bersangkutan. Semakin tinggi tingkat kepuasan dosen maka akan semakin tinggi pula tingkat kinerja yang dicapai. Hasil penelitian ini konsisten dengan penelitian Brahmasari dan Suprayetno (2008) yang membuktikan bahwa kepuasan kerja karyawan yang tinggi akan mampu meningkatkan kinerja perusahaan. Penelitian Nur (2013) juga menunjukkan hasil yang sama yaitu kepuasan kerja berpengaruh positif terhadap kinerja pegawai. Hasil penelitian Putri dan Latrini (2013) serta Devi (2009) juga membuktikan bahwa kepuasan kerja memiliki pengaruh yang signifikan positif terhadap kinerja karyawan. Penelitian yang dilakukan oleh Taurisa dan Ratnawati (2012), Rosita dan Yuniati (2016), dan Fauzi et al. (2016) menyimpulkan hasil yang sama dengan penelitian ini yaitu terdapat pengaruh positif yang signifikan antara kepuasan kerja terhadap kinerja karyawan. Hasil penelitian ini berbeda dengan hasil penelitian Al Afghoni dan Wahyudi (2011) yang menunjukkan tidak adanya pengaruh kepuasan kerja terhadap kinerja. 
Pengujian hipotesis kedua dilakukan dengan analisis jalur. Direct effect kepuasan karyawan terhadap kinerja karyawan adalah sebesar 0,392. Kepuasan karyawan terhadap kinerja karyawan dengan komitmen karyawan sebagai variabel intervening menunjukkan nilai indirect effect sebesar 0,339. Karena nilai indirect effect lebih kecil daripada nilai direct effect maka dapat dikatakan bahwa penelitian ini belum berhasil membuktikan peran komitmen karyawan sebagai variabel intervening. Kepuasan yang dirasakan oleh karyawan dalam hal ini dosen akan berdampak langsung terhadap kinerja dosen yang bersangkutan. Pada sampel yang diteliti kepuasan tidaklah membentuk komitmen yang pada akhirnya berdampak pada kinerja. Ketika seorang dosen merasa puas maka hal ini tidak mendorong timbulnya komitmen namun secara langsung dapat mempengaruhi kinerja. Sebagai dosen, komitmen akan terbentuk dengan sendirinya ketika profesi dosen merupakan sebuah panggilan. Hasil penelitian ini konsisten dengan penelitian yang dilakukan oleh $\mathrm{Al}$ Afghoni dan Wahyudi (2011) yang menyimpulkan bahwa komitmen organisasi tidak mampu memediasi pengaruh kompensasi dan kepuasan kerja terhadap kinerja guru. Hasil penelitian Rosita dan Yuniati (2016) menunjukkan hasil yang berbeda yaitu komitmen organisasional terbukti sebagai variabel intervening yang signifikan dalam hubungan antara kepuasan kerja dan kinerja karyawan.

\section{KESIMPULAN}

Penelitian ini berhasil membuktikan pengaruh positif kepuasan karyawan terhadap kinerja karyawan. Hasil penelitian ini memperkaya bukti empiris bahwa karyawan yang merasa puas dengan pekerjaannya akan mendorong kinerja karyawan tersebut secara positif. Kepuasan karyawan atas pekerjaannya akan menimbulkan keadaan emosional positif yang akhirnya memberikan tenaga lebih sehingga karyawan akan bekerja dengan semangat tinggi, teliti, dan pantang menyerah. Kepuasan yang minimbulkan perasaan penuh suka cita dalam bekerja akhirnya akan meningkatkan kinerja karyawan tersebut.

Namun, penelitian ini belum dapat membuktikan peran komitmen karyawan sebagai variabel intervening. Rasa puas atas pekerjaan yang timbul dalam diri seorang karyawan tidak sertamerta menimbulkan keterikatan karyawan terhadap organisasi tempat kerjanya. Kepuasan karyawan tidak dapat meningkatkan komitmen mereka terhadap organisasi dan akhirnya tidak dapat meningkatkan kinerja.

\section{Keterbatasan Penelitian}

Proses penyebaran kuesioner dalam penelitian ini dilakukan terbatas kepada para dosen perguruan tinggi swasta di wilayah Jakarta Barat.

\section{Saran}

Penelitian mendatang dapat menguji keberadaan variabel moderating dengan melihat hasil penelitian ini bahwa pengaruh positif secara langsung kepuasan karyawan terhadap kinerja karyawan telah terbukti. Penelitian selanjutnya juga dapat menguji variabel independen lain seperti motivasi karyawan, perilaku atasan, dan gaya kepemimpinan. Penelitian mendatang dapat memperluas wilayah penyebaran kuesioner atau melakukan perbandingan antara dosen dosen perguruan tinggi swasta dengan dosen perguruan tinggi negeri.

\section{REFERENSI}

Allen, N J \& Meyer J P. (1990). The Measurement and Antecedents of Affective, Continuance and Normative Commitment to the Organization. Journal of Occupational Psychology, 63, $1-18$

Al Afghoni, M. N. J., \& Wahyudi. A (2011). Pengaruh Kompensasi dan Kepuasan Kerja terhadap Kinerja Guru dengan Komitmen Organisasi sebagai Variabel Intervening. Jurnal Manajemen Sumberdaya Manusia, 5(1), 42-53

Brahmasari, I. A., \& Suprayetno, A. (2008). Pengaruh Motivasi Kerja, Kepemimpinan dan Budaya Organisasi Terhadap Kepuasan Kerja Karyawan serta Dampaknya pada Kinerja Perusahaan (Studi kasus pada PT. Pei Hai International Wiratama Indonesia). Jurnal Manajemen dan Kewirausahaan, 10(2), 124-135

Dessler, E. (2009). Manajemen Sumber Daya Manusia. Jakarta: PT Prehallindo

Devi, E. K. D. (2009). Analisis Pengaruh Kepuasan Kerja dan Motivasi terhadap Kinerja Karyawan dengan Komitmen Organisasional sebagai Variabel Intervening (Studi pada Karyawan Outsourcing PT Semeru Karya Buana Semarang). Tesis Tidak Dipublikasikan. Program Studi Magister Manajemen, Universitas Diponegoro, Semarang 
Djastuti, I. (2010). The Influence of Job Characteristics on Job Satisfaction, Organizational Commitment, and Managerial Performance: A Study on Construction Companies in Central Java. Integritas-Jurnal Manajemen Bisnis, 3(2)

Fauzi, M., Warso, M. M., \& Haryono, A. T. (2016). Pengaruh Budaya Organisasi dan Kepuasan Kerja terhadap Kinerja Karyawan dengan Komitmen Organisasi sebagai Variabel Intervening (Studi pada Karyawan PT Toys Games Indonesia Semarang). Journal of Management, 2(2)

Gallato, C. G., Rashid, S., Suryasaputra, R., Warokka, A., Reamillo, K. I. G., \& Abdullah, H. H. (2012). Fostering niches among SMEs in Malaysia through organizational commitment, leadership, organizational culture and job satisfaction. Journal of Innovation Management.

Ghozali, I. (2011). Aplikasi Analisis Multivariate dengan Program SPSS 19, Edisi 5, Semarang: Badan Penerbit-Universitas Diponegoro.

Horngren, C. T., Datar, S.M., \& Rajan, M.V. (2015). Cost Accounting: A Managerial Emphasis. 15th Edition. Pearson Education Limited.

Koesmono, H. T. (2005). Pengaruh Budaya Organisasi terhadap Motivasi dan Kepuasan Kerja serta Kinerja Karyawan pada Sub Sektor Industri Pengolahan Kayu Ekspor di Jawa Timur. Disertasi Tidak Dipublikasikan. Universitas Airlangga, Surabaya.

Mangkunegara, A.P. (2010). Manajemen Sumber Daya Manusia. Cetakan Keenam, Jakarta: PT. Rosda Karya.

Nur, S. (2013). Konflik, Stres Kerja, dan Kepuasan Kerja Pengaruhnya terhadap Kinerja Pegawai pada Universitas Khairun Ternate. Jurnal EMBA, 1(3), 739-749.

Putri, P. Y. A., \& Latrini, M. Y. (2013). Pengaruh Kepuasan Kerja terhadap Kinerja Karyawan Sektor Publik, Dengan In-Role Performance dan Innovative Performance sebagai Variabel Mediasi. E-Jurnal Akuntansi Universitas Udayana, 5(3), 627-638.

Robbins, S. P. (2008). Perilaku dan Manajemen Organisasi. Edisi Bahasa Indonesia.
Jakarta: PT Indeks Kelompok GRAMEDIA

Rosita, T., \& Yuniati, T. (2016). Pengaruh Kepuasan Kerja Terhadap Kinerja Karyawan dengan Komitmen Organisasional sebagai Variabel Intervening. Jurnal Ilmu dan Riset Manajemen, 5(1)

Spector, P. E. (2001). Job Satisfaction Application, Assessment, Cause, and Consequences. Sage Publications.

Taurisa, C. M., \& Ratnawati, I. (2012). Analisis Pengaruh Budaya Organisasi dan Kepuasan Kerja Terhadap Komitmen Organisasional dalam Meningkatkan Kinerja Karyawan (Studi pada PT Sido Muncul Kaligawe Semarang). Jurnal Bisnis dan Ekonomi, 19(1), 170 - 187.

Trisnaningsih, S. (2011). Faktor-faktor yang Mempengaruhi Kinerja Dosen Akuntansi. Jurnal Akuntansi \& Auditing, 8(1), 83-94.

Vignaswaran, R. (2005). The relationship between performance appraisal satisfaction and employee outcomes: A study conducted in peninsular Malaysia. Diakses dari http://dspace.fsktm.um.edu.my/bitstream /1812/729/1/MBA Research Project.pdf 